\title{
AWARENESS, ATTITUDES, AND BELIEFS OF THE GENERAL PUBLIC TOWARDS HIV/AIDS IN HYDERABAD, A CAPITAL CITY FROM SOUTH INDIA
}

R. T. SUDHA, D. T. VIJAY, V. LAKSHMI

\section{ABSTRACT}

CONTEXT: Information is the first step in human immunodeficiency virus (HIV) prevention. Ignorance about the disease and how the virus is transmitted can generate fear and prejudice towards those who are infected. AIM: To assess the awareness, attitudes, and beliefs of the general public toward HIV/AIDS in Hyderabad, the capital city of Andhra Pradesh. SETTING AND DESIGN: A cross-sectional study conducted for a period of 2 months in 2004 on 800 individuals living in Hyderabad. MATERIALS AND METHODS: A survey was conducted with a questionnaire titled 'General Population Behavioral Surveillance Survey.' The survey used a 5-part, 65-item questionnaire eliciting information about the knowledge of HIV (10 items), modes of transmission (20 items), ways of prevention (10 items), society's attitude toward HIV (15 items), and finally evaluation of Government's measures (10 items). RESULTS: Approximately $80.63 \%$ (645/800) of the study population were sketchily aware of HIV/AIDS, but had incorrect perceptions about the mode of transmission or prevention. Despite the vigorous outreach programmes, which the government and other organizations had carried out in the city, many people had several misconceptions about HIV or about people living with HIV/AIDS. CONCLUSION: As it was observed that awareness was more among the literates, the Government and Health educators should provide tailormade education programmes for those at the lower education levels.

KEY WORDS:attitudes; awareness; intervention programmes; literacy

AIDS is spreading in India at an alarming rate, fueled by an increasingly casual attitude towards sex, coupled with a tradition of public silence and reluctance to grasp the issues. There are fears here that the number of human

Department of Microbiology, Nizam's Institute of Medical Sciences, Hyderabad, Andhra Pradesh, India

\section{Corresponden}

$\checkmark$ Lakshmi

Nizam's Int of Microbiology

Nizam's Institute of Medical Sciences
Punjagutta, Hyderabad - 500082

India

E-mail: s_talasila@hotmail.com immunodeficiency virus (HIV)/AIDS cases could rise to such an extent that India overtakes South Africa as the world's most severely affected country. ${ }^{[1]}$ In India, Andhra Pradesh has the second highest number of recorded cases of HIV. Hyderabad, the capital city of the State of Andhra Pradesh, in 2004 had recorded $34.5 \%$ HIV positive cases in the high-risk group (include homosexual or heterosexual individuals, intravenous drug users who share needles, and infants born to mothers with HIV) and $0.75 \%$ in the low-risk group. ${ }^{[2]}$
Access to therapy is important, but it is no panacea to the crisis. Even a miracle drug may not overcome the stigma and address some of the most painful parts of HIV infection prejudice, rejection, hurt, ostracism, etc. The stigma around the disease could be attributed to cultural or religious beliefs or a lack of education. Increasing number of people are infected with growing drug abuse problems, prostitution, low levels of awareness towards the infection, etc.

Information, education, and communication (IEC) are the major steps in HIV prevention. They help in fighting fear, prejudice, and myths. Ignorance about the disease and how the virus is transmitted can generate fear and prejudice towards those who are infected. Recent studies and estimates suggest that effective preventive strategies could prevent approximately 29 million new HIV infections worldwide by 2010 .

The focus on HIV brought the need to assess the awareness levels of the general population and the society's perception towards HIV/AIDS and also for the evaluation of government's measures. Earlier most of the studies taken up had concentrated on high-risk group or some single-key population such as school children/ adolescents, ${ }^{[3]-[6]}$ prisoners, ${ }^{[7],[8]}$ rural or urban population, ${ }^{[9]}$ women, ${ }^{[10],[11]}$ health care workers, ${ }^{[12]}$ medical entrants, ${ }^{[13]}$ drivers, ${ }^{[14]}$ etc. As very few studies were taken up to assess the awareness levels in general population, but were not from the state of Andhra Pradesh, ${ }^{[15],[16]}$ we took up the following study in Hyderabad, the capital city of Andhra Pradesh with the aim to assess the awareness, attitudes, and beliefs of the general public towards HIV/AIDS.

\section{MATERIALS AND METHODS}

The study was essentially a survey conducted between February 2004 and March 2004 with the questionnaire titled 'General Population Behavioral Surveillance Survey.' Hyderabad has an estimated population of 40 lakhs. As male to female ratio in Hyderabad is 1000 $945,{ }^{[17]}$ the sample size of 800 was distributed as 412 males and 388 females.

The age distribution of the population of Hyderabad is $35.6 \%$ below 16 years, $25.7 \%$ between 16 and 29 years, and $38.7 \%$ for 30 years or more age group. Taking into consideration that children below 14 are not included in the study, 195 males and 185 females of age group 14 to 29 years and 217 males and 203 females of $>30$ years age were included in the study.

Literacy rate of population in Hyderabad is $79 \%$ and illiterates are $21 \%$. Accordingly, literacy and occupational distribution was based on the figures of the respective percentages in the population of Hyderabad.

As the sample size in each group was fixed before the survey, the target population and the places of study were selected in such a manner where people come from all the categories and are of all required age and occupational groups. For that, samples were taken from hospitals, schools, colleges, offices, factories, labor areas, and apartments/colonies located at different places in Hyderabad. Demographic profile of the study population is given in Table 1. 
Table 1: Demographic profile of the study population

\begin{tabular}{llll}
\hline Distribution & No. of males & No. of females & Total \\
\hline Age & 412 & 388 & 800 \\
$14-29$ years & 195 & 185 & 380 \\
>30 years & 217 & 203 & 220 \\
Mean age & 31 years & 26 years & 29 years \\
Literacy & & & \\
llliterates & 62 & 103 & 165 \\
Primary education & 117 & 94 & 211 \\
Secondary education & 118 & 94 & 212 \\
Graduates/PG & 115 & 97 & 212 \\
Occupation & & & \\
Agriculture/laborers/industrial workers & 4 & 2 & 6 \\
Service/business/unskilled workers & 195 & 37 & 232 \\
Students & 107 & 103 & 210 \\
Housewives/unemployed/casual laborers & 106 & 246 & 352
\end{tabular}

The survey used a 5-part, 65-item questionnaire eliciting information about the knowledge of HIV (10 items), modes of transmission (20 items), ways of prevention (10 items), society's attitude towards HIV (15 items), and finally evaluation of government's measures.

The questionnaire was constructed by combining the questions or statements from the General Population Behavioral Surveillance Survey questionnaire and the Voluntary Counseling and Testing Center (VCTC) questionnaire, both pretested and validated by the National AIDS Control Organization (NACO). Both these questionnaire were obtained from the Andhra Pradesh State AIDS control society (APSACS). The questionnaire was translated by the interviewers into the local languages, i.e., Telugu and Hindi, for those individuals who did not know English, and then back translation was done. Care was taken to see that no one missed out from answering any item. The questionnaire was pilot tested on 25-target population who were later again included in the modified questionnaire. Anonymity and confidentiality were maintained and ethical clearance was obtained from the institute's ethical committee. Each correct answer was given one point and both incorrect answer and 'do not know' response were not given any points. Data were fed into Epi-info, analyzed, and estimates of all the key variables and the indicators were calculated. The data were evaluated by chi-square test and a $P$-value of $<0.05$ was considered statistically significant. Odds ratios at $95 \%$ confidence intervals were also calculated.

The data collected were analyzed where the $P$ value was calculated by Mantel Haensze method from Epi-info.

\section{RESULTS} of males were more aware of HIV/AIDS compared to $71.39 \%(277 / 388)$ of females. actual study after being retested on the

Our study has shown that $89.32 \%$ (368/412)
The gender difference in the awareness of HIV/AIDS can be attributed to the literacy rate. Because females of Hyderabad are less literate than males, ${ }^{[17]}$ they are more ignorant of the virus. This clearly stresses the need of creating more awareness among the females.

Approximately $88.35 \%(561 / 635)$ of literates were aware of the infection compared to the awareness of infection in $12.73 \%(21 / 165)$ of persons with low literacy. Even these $12.73 \%$, who were aware of the infection, had received their information from the television, radio, posters, from work places, or through interpersonal communication. Therefore, to make persons with low-literacy rates more aware of infection, concentration should be placed on the measures, which need no formal education.

It was seen from the survey that different occupations have different awareness levels. The highest level of $97.62 \%$ (205/210) awareness was seen in students followed by $83.62 \%(194 / 232)$ of people in service, business or skilled/unskilled works, and the lowest of $69.89 \%(246 / 352)$ was seen in housewives, cultivators, agriculture laborers, and industrial workers. One major explanation for the high awareness of students is that they have been introduced to HIV/AIDS as a school curriculum. Another reason is that they are the class of general population who are more exposed to mass media, interpersonal communication, have access to various types of study material, etc. The housewives, casual laborers, agricultural laborers who have less awareness of HIV/AIDS are the ones who are either illiterates or have not been exposed to any information. This again stresses the importance of creating awareness among the illiterates and laborers.

It was observed from the study that the $97 \%$ subjects (370/380) in the age group of 14 to 29 years were more aware of HIV compared

Table 2: Knowledge of HIV/AIDS in the general public $(n=800)$

\begin{tabular}{|c|c|c|c|c|c|c|}
\hline \multirow[t]{2}{*}{ Questions mentioned in the section 1} & \multirow[t]{2}{*}{$P$ value } & \multicolumn{2}{|c|}{ Odds ratio $95 \% \mathrm{Cl}^{\dagger}$} & \multicolumn{3}{|c|}{ Responses in actual number (percentage) } \\
\hline & & (OR) & range & & No & Do not know \\
\hline Have you ever heard of HIV or AIDS & $<0.001$ & 17.32 & $13.41-22.36$ & $645(80.63)$ & 155 (19.38) & - \\
\hline Have you ever heard of STD & 0.230 & 1.13 & $0.92-1.38$ & $412(51.50)$ & $388(48.50)$ & - \\
\hline $\begin{array}{l}\text { If a person has STD, is he/she more } \\
\text { likely to get HIV }\end{array}$ & $<0001$ & 038 & $0.31-0.47$ & $306(3825)$ & 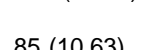 & $409(51.13)^{*}$ \\
\hline Just by looking at a person can you say & & & & & & \\
\hline $\begin{array}{l}\text { that a person is infected with HIV/AIDS } \\
\text { HIV infected individual without any symptoms }\end{array}$ & 0.271 & 1.12 & $0.91-1.36$ & $411(51.38)^{*}$ & $234(29.25)$ & $155(19.38)$ \\
\hline looks very weak & 0.028 & 1.25 & $1.02-1.52$ & $422(52.75)^{*}$ & $223(27.88)$ & $155(19.38)$ \\
\hline $\begin{array}{l}\text { he does not know it } \\
\text { An individual infected with HIV infection }\end{array}$ & $<0.001$ & 0.02 & $0.02-0.03$ & $105(13.13)$ & $127(15.88)$ & $568(71.00)^{*}$ \\
\hline $\begin{array}{l}\text { dies within a year or two } \\
\text { We can get the HIV test done on the }\end{array}$ & 0.841 & 0.98 & $0.80-1.20$ & $398(49.75)^{\star}$ & $236(29.5)$ & $166(20.75)$ \\
\hline $\begin{array}{l}\text { sample of blood } \\
\text { HIV infected person can easily get other }\end{array}$ & $<0.001$ & 6.95 & $5.55-0.71$ & $580(72.5)$ & $27(3.38)$ & $193(24.13)$ \\
\hline $\begin{array}{l}\text { diseases like TB, diarrhea } \\
\text { There are very few creses of HIV in }\end{array}$ & $<0.001$ & 51.31 & $37.65-69.99$ & $98(12.25)$ & $495(61.88)^{*}$ & $207(25.88)$ \\
\hline Andhra Pradesh & $<0.001$ & 0.10 & $0.08-0.13$ & $193(24.13)^{*}$ & $215(26.88)$ & $392(49.0)$ \\
\hline
\end{tabular}

† Confidence interval. 
to $65.48 \%$ subjects $(275 / 420)$ of age 30 years or more. This is mainly because 14-29 years is the age when most of the subjects are still going through their studies or have just finished their education again stressing the importance of education.

\section{Response to section 1: knowledge of HIV/} AIDS

It is evident from Table 2 that although, overall, $80.63 \%(645 / 800)$ knowledge of HIV is fairly good, most people do not know anything more than the words HIV or AIDS. Approximately $50 \%$ of them do not know the relation between STD, TB, and HIV. Surprisingly, half of the people who have heard of HIV/AIDS think that people with HIV look very weak and may die within a year or two.

\section{Response to sections 2 and 3: awareness} of modes of HIV transmission and

\section{prevention}

It was observed from Tables 3 and 4 that there was good awareness level toward the modes of HIV transmission and prevention but still some areas needed special attention. Even though many people were aware of the link between Blood and HIV, and between high-risk behavior and HIV, only $43.25 \%$ (346) were aware of the fact that HIV can be transmitted through breast-feeding, and only $43.5 \%$ (348) knew that IVD users could get infected with HIV. Approximately 64\% (512) were unsure/ unaware of the transmission through mosquito bite. Approximately $35.25 \%$ (282) were of the idea that healthy looking HIV reactive person cannot transmit the infection to others. Only $42.63 \%$ (341) were aware of the medicines that can control the HIV infection and only
$18.5 \%$ (148) knew about the HIV medicines to antenatal mothers.

\section{Response to section 4: society's attitude} towards HIV/AIDS

The extent of stigma and discrimination towards people living with HIV/AIDS (PLWHA) was found to be very high and there were many items in this section, which needed attention, as is shown in Table 5 . Approximately $73.75 \% \quad(590)$ of the respondents were ready to take care of their spouse/child, but only $18.13 \%$ (145) were willing to care for any other HIV positive family member. Almost nobody was willing to reveal the HIV status to others if he/she or other family member turns out to be reactive, which could be basically due to the fear of discrimination from society. Surprisingly, $51.13 \%$ (409) of the respondents wanted the public list of the positive people so that they can avoid them.

\section{Section 5: knowledge of government's} measures

Mass media like television, newspaper, magazines, etc., and the study material were the main sources of information of HIV for $79.75 \%$ (638) of respondents. Although $73.88 \%$ (591) were aware of the posters or hoarding about HIV, hardly few were aware of APSACS/NACO or prevention of parent to child transmission (PPCT)/VCTC programmes. The significance of red ribbon, which stands for care towards people living with HIV/AIDS is unknown to almost all the respondents. One important point noted was that $66.38 \%$ (531) of respondents felt that Government should implement more intervention programmes.
Table 3: Awareness of HIV transmission in the general public $(n=800)$

\begin{tabular}{|c|c|c|c|c|c|c|}
\hline \multirow{2}{*}{$\begin{array}{l}\text { Questions mentioned in the section } 2 \\
\text { actual numbers (Percentage) }\end{array}$} & \multirow[t]{2}{*}{$\mathrm{P}$ value } & \multicolumn{2}{|c|}{ Odds ratio (OR) } & \multicolumn{2}{|c|}{$95 \% \mathrm{Cl}+$ range } & \multirow{2}{*}{$\begin{array}{l}\text { Responses in } \\
\text { Do not know }\end{array}$} \\
\hline & & & & Yes & No & \\
\hline AIDS is caused by HIV & $<0.001$ & 0.23 & $0.18-0.28$ & $258(32.25)$ & $29(3.63)$ & $513(64.13)^{\star}$ \\
\hline $\begin{array}{l}\text { HIV is transmitted by blood } \\
\text { HIV can be transmitted by sharing }\end{array}$ & $<0.001$ & 4.12 & $3.33-5.11$ & $536(67.00)$ & $107(13.38)$ & 157 (19.63) \\
\hline infected needles & $<0.001$ & 10.60 & $8.35-13.44$ & $612(76.50)$ & $18(2.25)$ & $170(21.25)$ \\
\hline $\begin{array}{l}\text { HIV can be transmitted through unprotected } \\
\text { sexual contact } \\
\text { HIV can be transmitted from infected mother }\end{array}$ & $<0.001$ & 8.76 & $6.95-11.05$ & $598(74.75)$ & $11(1.38)$ & $191(23.88)$ \\
\hline $\begin{array}{l}\text { to unborn child } \\
\text { HIV can be transmitted through blood transfusion }\end{array}$ & $<0.001$ & 9.24 & $7.32-11.68$ & $602(75.25)$ & $22(2.75)$ & $176(22.00)$ \\
\hline $\begin{array}{l}\text { HIV can be transmitted through blood transfusion } \\
\text { HIV can be transmitted through breast feeding }\end{array}$ & $<0.001$ & 10.03 & $7.92-12.70$ & $608(76.00)$ & $9(1.13)$ & $183(22.88)$ \\
\hline $\begin{array}{l}\text { by infected mother } \\
\text { HIV can be transmitted by drinking in common }\end{array}$ & $<0.001$ & 0.58 & $0.47-0.71$ & $346(43.25)^{*}$ & $251(31.38)$ & $203(25.38)$ \\
\hline $\begin{array}{l}\text { cups or glasses } \\
\text { Persons having STDs, are at high risk of HIV }\end{array}$ & $<0.001$ & 0.01 & $0.01-0.01$ & $69(8.63)$ & $576(72.00)$ & $155(19.38)$ \\
\hline infection & $<0.001$ & 0.02 & $0.02-0.03$ & $106(13.25)$ & $83(10.38)$ & $611(76.38)^{\star}$ \\
\hline Like cold, HIV also is an contagious disease & $<0.001$ & 0.02 & & $98(12.25)$ & $548(68.50)$ & $154(19.25)$ \\
\hline You can get HIV even if you donate blood & $<0.001$ & 0.00 & & $33(4.13)$ & $608(76.00)$ & 159 (19.88) \\
\hline $\begin{array}{l}\text { HIV can be transmitted through mosquito bite } \\
\text { HIV can be transmitted through touching or }\end{array}$ & $<0.001$ & 0.32 & $0.26-0.39$ & $288(36.00)^{*}$ & $160(20.00)$ & $352(44.00)^{*}$ \\
\hline $\begin{array}{l}\text { shaking hands } \\
\text { HIV can be transmitted through living with }\end{array}$ & $<0.001$ & 0.00 & $0.00-0.00$ & $39(4.88)$ & $605(75.63)$ & $156(19.50)$ \\
\hline $\begin{array}{l}\text { HIV infected person } \\
\text { HIV can be transmitted through sharing }\end{array}$ & $<0.001$ & 0.00 & $0.00-0.00$ & $39(4.88)$ & 605 (75.63) & $156(19.50)$ \\
\hline utensils, clothes, soap, etc. & $<0.001$ & 0.03 & 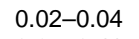 & $117(14.63)$ & $526(65.75)$ & $157(19.63)$ \\
\hline $\begin{array}{l}\text { HIV is transmitted through cough } \\
\text { Healthy looking HIV infected person can }\end{array}$ & $<0.001$ & 0.33 & $0.27-0.41$ & $293(36.63)$ & $209(26.13)$ & $298(37.25)$ \\
\hline $\begin{array}{l}\text { Healthy looking HIV infected person can } \\
\text { transmit HIV to others } \\
\text { Once infected with HIV he has the HIV }\end{array}$ & $<0.001$ & 0.64 & $0.53-0.79$ & $356(44.50)$ & $282(35.25)^{*}$ & $162(20.25)^{\star}$ \\
\hline infection for all his life & $<0.001$ & 11.53 & $9.06-$ & $618(77.25)$ & $27(3.38)$ & $155(19.38)$ \\
\hline $\begin{array}{l}\text { Injecting drug users can be infected with HIV } \\
\text { Can HIV be transmitted by barber and at }\end{array}$ & $<0.001$ & 0.59 & & $348(43.5)$ & $72(9.00)$ & $380(47.50)^{*}$ \\
\hline hair saloons & $<0.001$ & 3.53 & $2.86-4.36$ & $522(65.25)$ & $198(24.75)$ & $80(10.00)$ \\
\hline
\end{tabular}

Responses that need special attention. $\dagger$ Confidence interval.

Table 4: Awareness of HIV prevention in the general public $(n=800)$

\begin{tabular}{|c|c|c|c|c|c|c|}
\hline \multirow[t]{2}{*}{ Questions mentioned in the section 3} & \multirow[t]{2}{*}{$\mathrm{P}$ value } & \multirow{2}{*}{$\begin{array}{l}\text { Odds ratio } \\
\text { (OR) }\end{array}$} & \multirow{2}{*}{$\begin{array}{l}95 \% \mathrm{Cl}^{+} \\
\text {range }\end{array}$} & \multicolumn{3}{|c|}{ Responses in actual figures (percentage) } \\
\hline & & & & & & Do not know \\
\hline HIV can be prevented by condom use & $<0.001$ & 8.31 & $6.60-10.47$ & $594(74.25)$ & $6(0.75)$ & 196 (24.5) \\
\hline $\begin{array}{l}\text { Can HIV/AIDS be prevented by having } \\
\text { one faithful partner } \\
\text { Can we get blood transfusions before }\end{array}$ & $<0.001$ & 11.70 & $9.19-14.89$ & $619(77.38)$ & - & $181(22.63)$ \\
\hline it gets screened & $<0.001$ & 0.00 & $0.00-0.00$ & $17(2.13)$ & $602(75.25)$ & $181(22.63)$ \\
\hline There is a complete cure for HIV/AIDS & $<0.001$ & 0.02 & $0.01-0.02$ & 96 (12.00) & $548(68.50)$ & $156(19.50)$ \\
\hline Early therapy can absolutely cure HIV/AIDS & $<0.001$ & 0.02 & $0.01-0.02$ & $96(12.00)$ & $548(68.50)$ & $156(19.50)$ \\
\hline Is there any vaccine for HIV/AIDS & $<0.001$ & 0.00 & $0.00-0.00$ & $16(2.00)$ & $623(77.88)$ & $161(20.13)$ \\
\hline Are there any medicines to control HIV infection & $<0.001$ & 0.55 & $0.45-0.68$ & 341 (42.63) & $303(37.88)^{*}$ & $156(19.50)$ \\
\hline $\begin{array}{l}\text { Can HIV/AILS be prevented by avolding } \\
\text { contact with any used needles, syringes, } \\
\text { razor blades, etc. }\end{array}$ & $<0.001$ & 8.76 & $6.95-11.05$ & $598(74.75)$ & $46(5.75)$ & $156(19.5)$ \\
\hline $\begin{array}{l}\text { Are there any medicines that can be given } \\
\text { to HV infected mother for preventing the } \\
\text { child from getting infected } \\
\text { Do you think you are safe from getting }\end{array}$ & $<0.001$ & 0.05 & $0.04-0.07$ & $148(18.5)$ & $312(39.00)^{*}$ & $340(42.50)^{\star}$ \\
\hline $\begin{array}{l}\text { infected with HIV } \\
\text { inte sale lim geturg }\end{array}$ & $<0.001$ & 13.94 & $10.89-17.86$ & $631(78.88)$ & $14(1.75)$ & $155(19.38)$ \\
\hline
\end{tabular}

infected with HIV

$<0.001 \quad 13.94 \quad 10.89-17.86 \quad 631(78.88) \quad 14(1.75) \quad 155(19.38)$ 


\section{Table 5: Society's Attitude towards HIV/AIDS $(n=800)$}

\begin{tabular}{|c|c|c|c|c|c|c|}
\hline Questions mentioned in the section 4 & $\mathrm{P}$ value & Odds I & $95 \% \mathrm{Cl}^{+}$ & Responses it & actual numbe & is (percentage) \\
\hline & & & & & & \\
\hline $\begin{array}{l}\text { Is it important for you to not get infected } \\
\text { with HIV }\end{array}$ & $<0.001$ & 17.32 & $13.41-22.36$ & $645(80.63)$ & - & $155(19.38)$ \\
\hline $\begin{array}{l}\text { Will it be important for you to not infect } \\
\text { others if you had HIV }\end{array}$ & $<0.001$ & 10.03 & $7.92-12.70$ & $608(76.00)$ & $35(4.38)$ & $157(19.63)$ \\
\hline $\begin{array}{l}\text { Will you be willing to take care of your } \\
\text { HIV infected spouse/child } \\
\text { Will you be willing to take care of any other }\end{array}$ & $<0.001$ & 7.89 & $6.28-9.93$ & $590(73.75)$ & $45(5.63)$ & $165(20.63)$ \\
\hline $\begin{array}{l}\text { HIV infected member } \\
\text { If a member of your family has HIV, would }\end{array}$ & $<0.001$ & 0.05 & $0.04-0.06$ & $145(18.13)$ & $491(61.38)^{*}$ & $164(20.50)$ \\
\hline $\begin{array}{l}\text { you keep it a secret } \\
\text { Would you buy things from a HIV suspected }\end{array}$ & $<0.001$ & 4.95 & $3.99-6.16$ & $552(69.00)^{\star}$ & $16(2.00)$ & $232(29.00)$ \\
\hline $\begin{array}{l}\text { shop keeper } \\
\text { Should an HIV infected student be allowed }\end{array}$ & $<0.001$ & 0.38 & $0.31-0.47$ & $306(38.25)$ & $338(42.25)^{*}$ & $156(19.50)$ \\
\hline $\begin{array}{l}\text { to attend to school } \\
\text { Do you think it is advisable for people to tell }\end{array}$ & $<0.001$ & 0.40 & $0.32-0.49$ & $309(38.63)$ & $332(41.5)^{\star}$ & $159(19.88)$ \\
\hline others their 1 & $<0.001$ & 0.00 & $0.00-0.00)$ & - & $645(80.63)^{\star}$ & $155(19.38)$ \\
\hline $\begin{array}{l}\text { in schools } \\
\text { Do you think the names of people }\end{array}$ & $<0.001$ & 13.94 & $10.89-17.86$ & $631(78.88)$ & $5(0.63)$ & $164(20.50)$ \\
\hline $\begin{array}{l}\text { AIDS should be made public so that people } \\
\text { can avoid them } \\
\text { Would you feel comfortable using a common }\end{array}$ & $<0.001$ & 1.09 & $0.90-1.34$ & $409(51.13)^{*}$ & $235(29.38)$ & $156(19.50)$ \\
\hline $\begin{array}{l}\text { toilet with someone you knew or } \\
\text { suspected has HIV } \\
\text { Would you feel comfortable shar }\end{array}$ & $<0.001$ & 0.31 & $0.25-0.38$ & $286(35.75)$ & $348(43.50)^{*}$ & $166(20.75)$ \\
\hline $\begin{array}{l}\text { Would you feel comfortable sharing a meal } \\
\text { (not from the same plate) with someone that } \\
\text { you knew or suspected has HIV } \\
\text { Would you feel comfortable hugging/touching }\end{array}$ & $<0.001$ & 0.28 & $0.22-0.34$ & $276(34.50)$ & $368(46.0)$ & $156(19.50)$ \\
\hline $\begin{array}{l}\text { a person whom you knew or suspected to } \\
\text { have HIV infection } \\
\text { Chances of HIV infections are more in } \\
\text { (a) low class. (b) equal in all, and }\end{array}$ & $<0.001$ & 0.23 & $0.19-0.28$ & $259(32.38)$ & $386(48.25)^{*}$ & $155(19.38)$ \\
\hline (c) do not kno & $<0.001$ & - & - & $\begin{array}{l}\text { (a) } 261 \\
\text { (32.63) }\end{array}$ & $\begin{array}{l}\text { (b) } 45 \\
\text { (5.63) }\end{array}$ & $\begin{array}{l}\text { (c) } 494 \\
(61.75)\end{array}$ \\
\hline $\begin{array}{l}\text { yetting compulsory HIV test to be done before } \\
\text { narriage }\end{array}$ & $<0.001$ & 13.33 & $10.43-17.05$ & $628(78.50)^{*}$ & $17(2.13)$ & $155(19.38)$ \\
\hline
\end{tabular}

${ }^{*}$ Responses that need special attention.

t Confidence interval.

Other responses are given in Table 6.

\section{DISCUSSION}

The Andhra Pradesh government is working very hard toward this direction by adopting good advocacy policies, by having good planning and taking great efforts. The Government, with the help of APSACS and other government or private institutes has been carrying out a vigorous campaign to educate the public on HIV, including putting up posters in public areas, distributing pamphlets, spreading information through television and newspaper advertisements, including it in the secondary school curriculum, and is using many other strategies that include talk shows, lectures, peer education, leaflets, or workshops. It has provided many support systems for those infected and affected by HIV/AIDS. It has been running the PPTCT programmes successfully. Voluntary counseling and testing centers have been set up at 107 sites all over the state (12 are in
Table 6: Knowledge of government's awareness measures $(n=800)$

\begin{tabular}{|c|c|c|c|c|c|c|}
\hline \multirow[t]{2}{*}{ Questions mentioned in the section 5} & \multirow[t]{2}{*}{$\mathrm{P}$ value } & \multicolumn{2}{|c|}{ Odds ratio $95 \% \mathrm{Cl}^{+}$} & \multicolumn{3}{|c|}{ Responses in actual numbers (percentage) } \\
\hline & & & range & & No & Do not know \\
\hline \multicolumn{7}{|l|}{$\begin{array}{l}\text { How have you come to know about HIV? } \\
\text { (a) Mass media. }\end{array}$} \\
\hline (b) interpersonal communication & $<0.001$ & - & - & $\begin{array}{l}\text { (a) } 638 \\
\text { (79.75) }\end{array}$ & (b) $7(0.88)$ & $155(19.38)$ \\
\hline Do you know what folded red ribbon stands for? & $<0.001$ & 0.00 & $0.00-0.00$ & $11(1.38)$ & & $789(98.63)^{*}$ \\
\hline \multirow{2}{*}{\multicolumn{7}{|c|}{ Do you know how 1 December is celebrated }} \\
\hline & & & & & & \\
\hline all over the world & $<0.001$ & 0.02 & $0.01-0.02$ & $91(11.38)$ & - & $709(88.63)^{\star}$ \\
\hline $\begin{array}{l}\text { Do you watch any TV programmes on HIV/AIDS } \\
\text { Are you aware of any APSACS/AP govt. }\end{array}$ & $<0.001$ & 0.00 & $0.00-0.00$ & $31(3.88)$ & $470(58.75)^{\star}$ & $299(37.38)^{*}$ \\
\hline $\begin{array}{l}\text { sponsored events/shows like musical nights, } \\
\text { cultural shows, etc. } \\
\text { Have you seen any advertisements/slides }\end{array}$ & $<0.001$ & 0.00 & $0.00-0.01$ & $49(6.13)$ & $585(73.13)^{\star}$ & $166(20.75)$ \\
\hline shown in mass media in the last 2 months? & $<0.001$ & 0.04 & $0.03-0.05$ & $126(15.75)$ & $519(64.88)^{*}$ & $155(19.38)$ \\
\hline $\begin{array}{l}\text { Do you know anything about PPTCT } \\
\text { (prevention of mother to child transmission) or } \\
\text { VCTC (voluntary counseling and testing }\end{array}$ & & & & & & \\
\hline $\begin{array}{l}\text { centers) programmes } \\
\text { Have you seen any posters or information }\end{array}$ & $<0.001$ & 0.00 & $0.00-0.01$ & $51(6.38)^{*}$ & $58(7.25)$ & $691(86.38)$ \\
\hline material regarding HIV/AIDS at public places & $<0.001$ & 8.00 & $6.36-10.06$ & $591(73.88)$ & $54(6.75)$ & $155(19.38)$ \\
\hline $\begin{array}{l}\text { Do you think that govt. intervention } \\
\text { programmes being done are enough in } \\
\text { creating awareness about HIV }\end{array}$ & $<0.001$ & 0.02 & $0.02-0.03$ & $103(12.88)^{*}$ & $531(66.38)$ & $166(20.75)$ \\
\hline
\end{tabular}

Confidence interval.

Hyderabad) and their numbers have been increased year by year.

A nationwide survey, carried out in 2001 by NACO under general population behavioral surveillance survey (BSS), ${ }^{[18]}$ showed that across the country awareness of HIV is high (76.1\%), quite similar to our study results. It becomes quite difficult to compare the results of our study from other study results because there is no similar kind of documented study on HIV in general population from this area.

Despite the vigorous outreach programmes the government and other organizations carried out in the city, many people had several misconceptions about the HIV-positive people.

Our study has shown that $80.63 \%(645 / 800)$ of the study population from Hyderabad city was sketchily aware of HIV/AIDS but most of them had incorrect perceptions about the mode of transmission or protection [Table 2]

Only $24.13 \%$ (193/800) were aware that Andhra Pradesh has very high figures of HIV/ AIDS, an important information that the state government has to stress upon.

Despite the surveyed population's high level of HIV/AIDS knowledge, their own risk perception of potentially becoming infected with the virus is very low in almost all groups. Approximately $78.88 \%$ people thought that they were personally safe from getting infected with HIV. discriminated and rejected by their own loved ones. The disease is considered as a deserving punishment for immoral behavior.
Today, people with HIV/AIDS are regularly 
Discrimination can become the hardest part of living with the HIV infection, creating a climate that is a private hell for those infected and affected. In many regions, people with HIV have been thrown out of their homes, rejected by families, turned away from jobs, and had their children expelled from schools. Stigma generally makes the disease more difficult to discuss and harder to deal with. It can spread infection through misunderstanding. Some people with HIV infection go for years without telling a soul.

The study has brought into light some of the important issues and immense and urgent efforts are needed towards making people more caring and accepting PLWHA, which can be mainly achieved through raising the levels of knowledge about HIV and its ways of transmission.

The study reported here has confronted several limitations. First, due to unwillingness of the respondents, sample size had to be limited to 800 . Second, restriction in asking questions concerning sexual beliefs and behaviors as was observed in the pilot study, made us slightly change the questionnaire. Third, because of the nature of the questionnaire, the honesty of individuals' responses may be questioned.

\section{SUMMARY}

Our study has observed a significant good level of awareness towards HIV but more sustained efforts are needed to make the public fully aware of the modes of transmission and prevention of HIV/AIDS. Open discussions about HIV are still rare in Hyderabad. General awareness of HIV/AIDS-related issues must be increased in order that people will understand how to protect themselves, reduce their stigma and discrimination towards people living with HIV/AIDS because overcoming stigma and discrimination is the key to control the HIV epidemic.

Although Andhra Pradesh is suffering from the burning problem of HIV, general population of Hyderabad thinks that they are in a State that is safe with very few cases of HIV/AIDS. Many are not aware that the Andhra Pradesh is a State in India with second highest recorded number of HIV cases. Furthermore, being the capital city of Andhra Pradesh, the population of Hyderabad should be more aware of HIV and its ways of transmission and prevention when compared to other cities or rural population.

The various measures, which the government has been implementing, are either not enough to create awareness, or they are not reaching the targeted population. There is an immense need from the side of the government in taking measures, which would make the general public aware of the country's AIDS crisis. As most of the Indian population are illiterate and as it was observed from our study that awareness was more among the literates, government and health educators should provide tailor-made education programmes for those at the lower education levels. Because HIV infection is a dynamic process and could change as a function of time, more and more of similar studies targeted at general population are needed at regular intervals to test the results of the preventive measures and the efficacy of the implemented policies.

\section{REFERENCES}

1. Unaids.org [homepage on the Internet]. Report on the global HIV/AIDS epidemic [updated 2005 April 2; cited 2005 April 9]. Available from: http:/ /www.unaids.org/epidemic_update/report/ index.html.

2. National AIDS Control Organisation [homepage on the Internet]. http://www.nacoonline.org. HIV Sentinel Surveillance - 2004 [updated 2005 March 23; cited 2005 April 9].

3. Sodhi S, Mehta S. A comparative study of girls of two senior secondary schools of Chandigarh. Man India 1997;77:259-66.

4. Chakraborty J, Purohit A, Shah S, Kalla S, Purohit S. A comparative study of the awareness and attitude of HIV / AIDS among students living in India and migrants to the United States. J Assoc Physicians India.1996;44:237-9.

5. Baxi S, Baxi RK., Hazara Maya: Knowledge of HIV/AIDS among college students of Baroda university. J Obst Gyn India 1994; 44:784-9.

6. Lim VKG, Teo TSH, Teo ACY, Tan KTL. HIV and Youths in Singapore- Knowledge, Attitudes and Willingness to Work with HIV-Infected Persons. Singapore Med J. 1999; 40:410-6.

7. Rajkumar C, Senthilkumar R, Sathyanarayanan $D$, Murali R, Pugalendhi R. Impact of an educational programme on the HIV/AIDS knowledge and practices among prisoners in Chennai, India. IAS Conference - Bangkok 2004 July $11-16$.

8. Nakhaee FH. Prisoners' knowledge of HIV/AIDS and its prevention in Kerman, Islamic Republic of Iran. East Mediterr. Health J. 2002;8:725-31.

9. Bhatia V, Swami HM, Kaur AP. An intervention study to enhance AIDS awareness among underprivileged population in Chandigarh. Indian J Dermatol Venereol Leprol 2004; 70:87-91.

10. Choi Fung Ho and Alice Yuen Loke. HIV/AIDS knowledge and risk behaviour in Hong Kong Chinese pregnant women. Journal of Advanced Nursing 2003;43:238.

11. Shrotri A, Shankar AV, Sutar S, Joshi A, Suryawanshi N, Pisal H, et al. Awareness of HIV/ AIDS and household environment of pregnant women in Pune, India. Int J STD and AIDS 2003;14:835-39.

12. Bianchini E, Agnoletto V, Passarello $\mathrm{P}$, et al. Evaluation of levels of awareness regarding the prevention of occupational risk for HIV transmission among a group of health care workers. Int. Conf. AIDS 1992; 8:202.

13. Chatterjee G; Chakraborty I; Gosh JM. Knowledge about HIV and AIDS among medical entrants: a questionnaire study. Indian Journal of Dermatology 2001; 46:80-2.

14. Abdelmoneim I, Khan MY, Daffalla A, Al-Ghamd S, Al-Gamal M. Knowledge and attitudes towards AIDS among Saudi and non-Saudi bus drivers. East Mediterr Health J. 2002;8:716-24.

15. Rashed A. Al-Owaish, Mohamed AA, et al. Knowledge, attitudes, beliefs and practices of the population in Kuwait about AIDS-a pilot study. Eastern Mediterranean Health Journal 1995;1:235-40

16. Nicole M. Lanouette, Rivo Noelson, Andriamahenina Ramamonjisoa, Sheldon Jacobson and Jeffrey M. Jacobson. HIV- and AIDS-Related Knowledge, Awareness, and Practices in Madagascar. American Journal of Public Health 2003;93:917-19.

17. Directorate of census operations, Andhra Pradesh [updated 2002 April 06; cited 2005 January 6]. Available from: http:// census.ap.nic.in/p2tabmenu.html.

18. National AIDS Control Organisation, Ministry of Health \& Family Welfare, Govt. of India, New Delhi. National Baseline General Population behavioural Surveillance Survey - 2001. 